\title{
HOMENAJE A LUIS
} ASTEY

Ma. Antonieta R. Vizcarra

Me uno a todos ustedes en forma sencilla al homenaje a Luis Astey, por el cariño propio y en recuerdo a la gran amistad que hubo entre él y mi padre.

Me remontaré a la ciudad de Monterrey, por el año de 1945, año en el que llegó para formar parte de la planta de maestros del Instituto Tecnológico de Monterrey, que iniciaba sus actividades académicas.

La intensidad de su trabajo y su interés por los libros, lo llevaron a estructurar la biblioteca del Tec, y posteriormente fue designado Director de la misma. Él siempre cuidó de que los libros que se adquirieran fueran de alto valor en cuanto a su contenido, se orientaba siempre hacia el fondo de las cosas, más que por la forma. Era un hombre extremadamente culto, a la vez que muy sensible al factor humano, y con un gran conocimiento de los libros, con lo que ideó un sistema respetuoso tanto de las personas como de los libros, con el objeto de que se pudieran consultar aún aquellos ejemplares considerados como únicos, concentrados en la Biblioteca Cervantina del Instituto, y los estudiantes agradecían y respondían respetuosos hacia aquella consideración de su estimado Director. Cuando se vino a la ciudad de México, a pesar de que dejó perfectamente bien organizada la Biblioteca, se sintió un vacío muy grande; pero él siempre fue de la opinión de que nadie es insustituible.

Quisiera mencionar que no sólo despertaba el interés en las personas que habían escogido el camino de las Letras, sino también en estudiantes de otras carreras. Esto era debido a que aquéllos a los que por 
MA. ANTONIETA R, VIZCARRA

suerte les tocaba tomar clases con él, como de Historia de la Cultura por ejemplo, quedaban motivados para seguir cultivándose, pues él hacía de cada clase una brillante y amena conferencia, y la transmitía de tal manera, que parecía que hubiera vivido en la época y lugar al que se refería, especialmente si se trataba de Literatura griega. Sus alumnas de la carrera de Letras, cariñosamente le llamaban "Zeus tempestuoso".

En general los alumnos buscaban en él al maestro, ya que era accesible y una persona interesada en el desarrollo humano. Fue precisamente esta similitud de intereses lo que hizo que mi padre y él se encontraran y naciera una gran amistad. Intereses que despertaban a su vez la inquietud en sus alumnos por leer o incluso por participar, ya fuera como actores, escenógrafos o cantores en obras del teatro clásico griego o dramas latinos medievales traducidos por él mismo, como el Sponsus. Ésta obra fue representada en 1967 y 1969 con instrumentos y música de la época, para lo que participó entusiasta el gran maestro de música Ramiro Guerra.

Luis Astey fue un investigador incansable, y en este momento creo justo mencionar que mi padre logró convencerlo de la importancia de publicar sus investigaciones, y fue así como por primera vez se editó su traducción del fragmento que hasta entonces se conocía del poema babilónico de la creación Enuma Elish. Por su publicación en 1961 en Ediciones Sierra Madre se difundió a nivel regional, lo cual sirvió para la edición y publicación de muchas más de sus investigaciones, incluso para la reedición del Enuma Elish en 1989 por la Universidad Autónoma Metropolitana de la ciudad de México, finalmente con trascendencia internacional.

Con su muerte México pierde un gran investigador y un gran humanista. Los que vivimos muy cerca de él perdimos un gran maestro y un gran amigo.

Muchas gracias. 